\title{
Spatial enactments in emancipatory higher education pedagogies
}

\author{
Dirk Postma \\ College of Education, Unisa \\ Corresponding Author: postmdj@unisa.ac.za
}

(Submitted: 12 April 2020; Accepted: 18 August 2020)

\begin{abstract}
The focus on the role of space in social sciences provides new perspectives on the possibilities for emancipatory pedagogies in higher education. The posthumanist insight into heterogeneous agency draws attention to the agential roles of spaces. The implications of spatial agency are investigated through a diffractive reading of Rancière's emancipatory pedagogy with a spatial typology. A spatial typology originating from the social studies of science distinguishes between regional, network, fluid and fire spaces. Whereas banking education could be associated with regional spaces, progressive and critical pedagogies are closer to fluid spaces. In contrast, it is shown how the emancipatory pedagogy of Rancière is made possible through the interference of regional and fire spaces. The spatial analysis draws on the powerful effects of interferences (or diffractions). The significant finding of this investigation is that the possibility for emancipation is not ascribed to the spaces as such, but to the interference of regional-and fire spaces. Powerful effects are possible when regional spaces enable an awareness of the equality of intelligence and fire spaces the transformation of the world.
\end{abstract}

Keywords: critical pedagogy, emancipation, higher education, Rancière, spatialities

\section{Introduction}

The calls for higher education to decolonise and to promote social and epistemic justice also require a pedagogical response. The pedagogical relation between educator and student is a key element in the generation of decolonial knowledges which respond to the claim typical of coloniality that the 'primitive people could not use [their] minds or intellects' (Smith, 2012: 26). Such a pedagogical response has not yet been well articulated in the reflections on the 'Fall' students protests of 2015/6 in South Africa. It is possible that this response is caught up in the opposing demands critical pedagogies encounter: On the one hand, it wants the student-activist to think independently and critically about the ways powers are distributed or alienation is produced. On the other hand, it wishes to reveal to students the objective condition of their oppression/alienation. The two demands seem to contradict each other because the imposition of a 'truth' prevents the independent search for a 'truth'. These opposing demands also relate to 
two opposing kinds of pedagogical relations: On the one hand is the enlightened educator who emancipates students by demystifying the working of power in oppressive structures, by liberating them from ignorance and dogmatism, and by unmasking the effect of ideology on false consciousness (McLaren, 1997). On the other hand is the Freirean facilitator (Freire, 2005) who searches for knowledge alongside the students. It is therefore a question what the role of the educator is within the quest for the decolonisation of the university. The default response seems to favour that of the enlightened educator. This is, for example, expressed by Ford (2016: 190) for whom the teacher has to play the role of the authoritative (Communist) Party. A more nuanced response is provided by Biesta (2017) who maintains that it is the task of the educator to transmit something meaningful to the student.

The focus on the relation between the educator and student shifts in post-humanist theorising (Hayles, 1999) towards heterogeneous practices where not only humans, but multiple others participate. Part of the post-humanist shift is the attention to the role of spatialities in social practices (Lefebvre, 1991). The material turn (Barad, 2003) in the sciences has emphasised the important role of nonhuman agencies and the spatial turn in the human and social sciences has brought the productions of space to the fore. This means that space is performed through heterogeneous practices, and in its turn performs such practices. An investigation of pedagogical relations must therefore be preceded by the ways relations are produced through spatialities. The investigation into the relations between the emancipatory educator and the student has to be undertaken within the context of the spaces of education.

Both the educator-centred and the student-centred approaches of critical pedagogies assume particular spatial configurations. Different kinds of spaces affect pedagogical practices in diverse ways. They contribute towards the shaping of agencies and subjectivities, knowledges, and definitions and practices of freedom. Seen from this perspective, the space of enlightening education is bounded in order to capture the attention of students and to transmit insight into the objective condition and the truth of their oppression and alienation. The fluid space of the egalitarian educator, on the other hand, enables the expression of the student's voice through the reversal of the roles of educator and student. The question for critical pedagogies is therefore not only which pedagogical process and relations are likely to promote emancipation, but also how pedagogical spaces should be generated.

In higher education, spaces tend to have become open and fluid through 'blended learning' and open, distance, and e-learning (ODEL). Most residential universities introduced ODEL programmes to enable learning regardless of place, age, or gender. These initiatives have been seen as empowering and 'learner-centred'. The traditional, bounded, lecture room is no more the only or the ideal learning space. Learning does not only happen within the confined space of the university campus but also happens anywhere and anytime. The question is therefore also how the performance of spaces in higher education could contribute towards emancipatory learning.

Spatial analyses have been done in education generally (Mulcahy, 2007, 2015; Sørensen, 2009) and in higher education in particular. Ferrare and Apple (2010) and Gulson and Symes 
(2007) show how spaces are gendered, classed and 'raced'. Lefebvre's notion of space has been used by Ford (2016) and Wubbena (2017) to investigate spaces of learning and teaching, and studying during the rebellion in Baltimore and during student protests in Chile, respectively. The role of space in higher education pedagogies has received attention from critical theorists such as Walker and Wilson-Strydom (2017). Grellier (2013) draws on the Deleuzian notion of the rhizome to investigate how the voices of marginalised groups such as first-year students and sessional tutors challenge the massification of education. Bayne, et al. (2014) investigate the relations between the bounded space of the campus and the network spaces of distance learning. They found that the symbolic space of the campus remains an ideal missed by those studying at a distance.

While some of these spatial analyses have been done from critical perspectives, a key issue for Edwards (2014) is that space itself remained largely untheorized. With this he has in mind that the analyses focus more on what is happening inside spaces than on the structuring of space itself. Such a structuring, or enactment, of space is important from a post-humanist perspective where human agency is only part of the agential effects of heterogeneous assemblages. The shift towards a spatial analysis of education allows an investigation of the ways pedagogical relations and knowledges are the effect of particular spatial configurations. This leads to the question whether some spatial configurations are more conducive to emancipatory educational practices than others.

This article investigates emancipatory pedagogical spaces by means of the critical pedagogy of Rancière. Emancipatory education entails for Rancière the awakening of the intellect of the student to question the dominant order of necessity in order to enact a different world. While Rancière increasingly attended to materiality (Boano and Kelling, 2013), a spatial typology is superimposed on his pedagogy in order to detect diffractional effects. With reference to the questions mentioned so far, the central question is therefore: How could the critical pedagogy of Rancière be used to inform the performance of spaces in emancipatory education? The aim is to detect how differences could be affected when Rancière's pedagogy is read diffractively (Barad, 2007: 71) with a spatial typology. The methodology of diffractive reading used here traces the effects when one text interferes with another. The hope is that we might get some insights into the ways activist and resistant subjectivities could be enabled through the enactment of pedagogical spaces.

\section{Multiple spatial performances}

The spatial turn in the social and human sciences has drawn attention to how spaces are performed and what the effects are. Lefebvre (1991), who initiated the spatial turn, has indicated that space is performed in contested ways. He distinguished between representations of space (conceived space), representational spaces (lived space), and spatial practice (perceived space). Representations of space refer to space as conceived by city planners and establishes a normative order conducive to capitalist production. Representational space is the lived space of everyday life found in folk stories, art, or underground activities. Spatial practices mediate between the 
previous two spatialities in the production of social relations. In their use of Lefebvre's analysis of space in education Ford (2016) investigates the revolutionary elements of learning in conceived space, studying in lived space, and teaching in perceived space. Wubbena (2017) also shows how student activism could be analysed through these spaces.

While Lefebvre has been used to provide a spatial analysis of Rancière's political philosophy (Büscher-Ulbrich, 2020), the approach to space in this study is different in two ways: Firstly, space is understood sociomaterially as a heterogeneous agency; secondly a typology of space is used where the focus is not on what happens 'in' the space but on the structuring of space itself. The benefit of such a formal approach is that it does not assume that specific kinds of spaces have particular effects. This allows for a more careful analysis of the effects of spatial relations. It is not assumed that certain kinds of spaces are as such emancipatory or oppressive.

Space is not a given entity within which practices take place, but a sociomaterial practice that could be performed in different ways. Once it is realized that space needs not be understood in terms of the three-dimensional Euclidian coordinates, it becomes possible to investigate the heterogeneous patterns of relations such as differences, similarities, continuities and breaks (Edwards, et al., 2011). In her investigation of the spatial materialities of learning Sørensen declares that her

... intent is to describe space as an expanded web of relations that may have nothing to do with geographic terrains. That is, space consists of emerging relational formations in which human and nonhuman components may take part, and the components that do take part contribute to performing these spatial formations. (2009: 74-75)

Edwards, et al. state that spatial

orderings are not about human subjects per se, but are material assemblages of subjectsobjects that interrupt and affect, question and promise. (2011: 222-223)

The different patterns of relations allow for a social typology of space. Spatial typology has its origin in Mathematics where different kinds of spaces other than the three-dimensional Euclidean are imagined. Social typology describes how spaces are produced through patterns of relations and different kinds of objects. The social typology is about properties, relationships, and interactions.

In particular, it [typology] invents spaces by thinking up different rules for defining the circumstances in which shapes will change their form or not. It is possible to devise indefinitely many rules for shape invariance. (Law and Mol, 2001: 612)

Such a typology is developed in the studies of science, technology, and society (STS) (de Laet and Mol, 2000a; Law and Mol, 2001; Mol and Law, 1994). They question the universal claims 
of scientific knowledge by asking where science happens. The belief in the universality of scientific knowledge implies that it is equally valid and applicable regardless of where it happens. In contrast to this notion of scientific universality, STS scholars ask about the kinds of spaces where science is practised and how these spaces shape scientific legitimacy, as well as the possibility for scientific knowledge to travel elsewhere. They identify four types of spaces: regional, network, fluid, and fire.

Drawing from this spatial typology, this article investigates how spaces could be performed in education. While this typology has been used by others to analyse education (Mulcahy, 2007, 2015; Sørensen, 2009), the focus here is on possible ways to promote emancipation in education.

In what follows the different types of spaces, as identified by the STS scholars, are investigated to establish implications for education and emancipation. While the focus in the rest of the article is on regional - and fire spaces, a brief overview is given of all four types of spaces for comparative purposes.

\section{Regional space}

Law and Mol (2001) see the laboratory where knowledge is generated as the typical regional space. The boundaries of the laboratory are carefully controlled to prevent contamination from the outside. The production of a stable space enables belonging and identities. This space is characterized by power hierarchies, well-established roles, protocols, and methodologies through which objective knowledge is produced.

The regional pedagogical space is the classroom bounded by walls and a closed door. The roles and powers of educator and student are clearly defined and demarcated. The effectivity of the learning process is dependent on the boundaries which prevent interruptions. The distribution of power in the classroom is made possible by clearly separated places for educators and students. Regional space makes a static body of knowledge possible reinforced by a fixed curriculum and standardized assessment. It performs a subjectivity with a strong sense of identity. Sørensen (2009) describes it as a 'resonance' space and Bayne, et al. (2014) describe the residential university in terms of regional spaces. It is also the kind of space performed in 'banking education' (Freire, 2005) since it allows for the hierarchical educator/student divide.

Regional space is, however, not necessarily oppressive. Mulcahy (2015) reports on the need of primary school children to create regional spaces in a classroom organized as a fluid space. She reports that, while policies aim to prepare these students for the 21st century through fluid spaces, they found the need to move furniture around to create 'my space ... where I am working' (Mulcahy, 2015: 510).

\section{Network space}

The spatiality of regional spaces dominated social thinking for a long time until it has been augmented by the notion of network societies (Castells, 1996). Whereas regional space ensures that scientific knowledge and processes remain intact, Law and Mol (2001) show that the establishment of a network is needed for scientific knowledge to travel to other locations. For 
this to happen the regional space must be replicated in a geographically different place. Latour's (1987) notion of the immutable mobile indicates that, even though geographical movement takes place (mobility), entities remain static in the network space (immutability). In this way, network spaces enable control over geographical distance as in the cases of globalization and colonialism.

The success of open and distance learning has been related to the enactment of network spaces. From the analysis of Bayne, et al. (2014) one could see how the regional space of the residential university is extended through the network of distance education. Network space is, however, ambiguous: One the one hand it provides through open and distance learning opportunities to students regardless of distance, age, gender, or class; on the other hand it allows centralized forms of control which prevent alternative kinds of knowledge.

\section{Fluid space}

Whereas objects remain stable in network and regional spaces, as mutable mobiles they change in fluid space. For the object to persist, the changes are incremental and continuous in response to contextual factors. Abrupt changes would make the object to disappear or to become something else. (Law and Singleton, 2005: 338). De Laet and Mol (2000b) illustrate this with reference to the use and adaptation of a water pump in remote areas of Zimbabwe. While many parts of the pump were replaced with items at hand, the pump remains the same. The identification of fluid space is significant for STS scholars. They found that the difference between spaces is at times fluid because of changing boundaries and relations:

Sometimes, we suggest, neither boundaries [emphasised in the topology of the region] nor relations [emphasised in the topology of networks] mark the difference between one place and another. Instead, sometimes boundaries come and go, allow leakage, or disappear altogether, while relations transform themselves without fracture. Sometimes, then, social space behaves like a fluid. (Mol and Law, 1994: 643)

Fluid spaces in education are enacted when the boundaries between the classroom and the community, different disciplines or age groups are transgressed. For Giroux (2005) the borders of cultures, languages, literacies, histories, sexualities and identities have to be crossed and for bell hooks (1994) teaching is a transgression of established boundaries. The so-called 21st century skills are closely associated with fluid pedagogical spaces. By facilitating collaboration, flexibility, and critical and creative thinking, these spaces could also promote the human resources required by the global market economy. Edwards, et al. (2011: 226) point to the ambiguity of fluid spaces which break down binary divisions such as educator/student, male/female, but also play in the hands of liquid modernity (Bauman, 2007) where humans must continually be reskilled as resources for the capitalist economy. 


\section{Fire space}

The spatial typology of fire is significant since it represents a move away from the metaphysics of presence in both temporal and physical terms of the regional and network spaces. Law and Mol describe it as follows:

If water is the element of flow, then (at any rate in some of its versions) fire is the element of passion, action, energy, spirit, will, and anger, not to mention creative destruction and sexuality. (2001: 615)

It differs from fluid space: continuity is only possible when there are breaks and discontinuities; the flickering between presence and absence refers to the role of the unseen (others) in maintaining the seen. These others do not only refer to humans, but also the 'missing masses' of nonhumans (Latour, 1994).

Law and Mol (2001) show how an object such as a fighter plane performs the fire space where the presence of some elements are dependent on the absence of others. For example, present is the mathematical formula used to design the size and shape of the wing which enables the plane to take off on a short runway. Absent in the formula are the Russians whose bombing of the airstrips would necessitate a short-distance take-off. Absent are also the bodies of pilots for whom there is a physiological limit to the acceleration of the aircraft.

Law and Singleton (2005) provide a spatial analysis of the 'object' alcohol liver disease. While they found that the object could be described in relation to three types of space (regional, network, fluid), they found that its complexity is better captured when described as a fire-object. The object is not a static entity found in different locations but is enacted differently depending on where it is. In each of the contexts a different combination of presences and absences is found. In the hospital alcohol is absent since total withdrawal is a precondition of treatment. In the community the absence of alcohol is not as important as socialising with family and a healthy lifestyle. In a private practice alcohol abuse might be seen as the lesser evil in comparison with other addictions. An object, for them is 'a pattern of presences and absences' (Law and Singleton, 2005: 342-343).

By using the metaphor of fire to describe objects and spaces, Law and Singleton emphasise it as energetic, generative, and transformative. They particularly have a bush fire in mind which jumps from place to place destructively, but also creatively and unpredictably. The spatial performances feed on otherness, the differences between the flames that are present and the absent cinders. They describe such a fire-object 'in the form of a dancing and dangerous pattern of discontinuous displacements between locations that are other to (but linked with) each other '... it lives in and through the juxtaposition of uncontrollable and generative othernesses' (Law and Singleton, 2005: 347). Fire is not portrayed as something that only destroys: 
The unbounded otherness of undomesticated fire, we insist, is generative. It is productive. It depends on and creates the unknowable and the unexpected. And this is only sometimes destructive. (Law and Singleton, 2005: 349)

In the space of fire, the changes are not gradual as in fluid spaces, but abrupt and discontinuous. It means that 'the continuity of shape is an effect of discontinuity'. It is a 'flickering relation between presence and absence' (Law and Moll, 2001: 615) which implies a dependence of absence (what cannot be made present) on presence and the dependence of presence on absence.

\section{Multiple spaces in education}

This typology could be used to investigate how different spaces affect education by producing different versions of subjectivities, knowledges, and values. The discussion of the typology has also shown that, while spaces are not neutral, they are ambiguous in relation to oppressive or emancipatory pedagogical practices.

This ambiguity is present in the investigations of Mulcahy (2015). She investigates the effect in classrooms of progressive policies based on fluid spaces such as an open classroom. She found that children created a haven in bounded space when they felt threatened by the open space of the classroom by arranging chairs and cushions. While regional space is more often associated with a transmission mode of education, the children found the withdrawal within a regional space necessary for the development of an own sense of self and of independent ideas. Edwards, et al. (2011) use a 'mobilities' approach to investigate regional and fluid spaces in higher education. They contrast regional -(moorings) and fluid (mobile) spaces in a university course using semantic technologies. While the regional spaces refer to the traditional classroom and curriculum where organized knowledge is provided, mobilities refer to moments when students are taken out of their 'comfort zones'. While such a shifting of student subjectivity is usually welcomed, the authors show how academics experience discomfort when students do not remain within the boundaries of the discipline.

The investigations reported above show how educational practices are performed through multiple ambiguous spaces. While regional education tends to maintain standards of knowledge and fixed identities, networks allow stabilities (immobilities) to travel over distances. In fluid spaces knowledge boundaries and fixed educational relations are transgressed so that new knowledges could evolve rhizomatically. The educational value of fire spaces relates to epistemic breaks and discontinuities. The multiplicity of education and the ambiguity of educational spaces provide the backdrop against which the possibilities for emancipatory and decolonial education could be investigated.

\section{Aesthetics, politics, and education}

This investigation focuses on one possible way to configure spaces in education through a diffractive reading of the emancipatory pedagogy of Rancière with a spatial typology. 
Rancière's emancipatory pedagogy has to be understood against the background of central elements of his philosophy. While Rancière shifts his attention over time from politics towards aesthetics and art, the recognition of the coherence in his writing (Deranty, 2007) allows for explorations of the impact of one element on the other. For example, the close relation between the intellectual and the sensible (McQuillan, 2011: 25) is significant for exploring materiality in Rancière's thinking. If the different elements in Rancière's thinking (equality of intelligence, the aesthetic partitioning of the sensible, and the politics of dissensus) are related to each other, what appears is an intelligent aesthetics of dissensual politics.

\section{Equal intelligence}

The concept equal intelligence underlies Rancière's views of politics, aesthetics and education. His presumption of radical equality separates him from the Marxist orthodoxy, in particular the epistemology of Althusser. It is significant for Rancière that the 1968 revolt in France was driven by the workers and not by the intellectuals' critical theories as theorised in Marxist orthodoxy. This led Rancière to critique his mentor, Althusser's, view that the intellectual superiority of intellectuals entitles them to teach the ignorant workers about the conditions of their oppression. His dissertation Proletarian Nights (2012) developed this notion of equal intelligence through an investigation of workers' intellectual work.

According to Rancière inequalities could only be addressed if we start from the assumption of equality. This assumption challenges the fundamental belief in inequality in Western thinking, originating from Plato's distinction between those who are destined to rule and those who are to be ruled, or those who know over those who do not (Rancière, 2001). Rancière also detects in critical and progressive traditions this belief in a prior inequality. Their point of departure is the notion of inequality which can only be overcome through restorative processes. The same assumption is present in critical and progressive education. For Rancière we have, on the contrary, to assume that everyone is equal. This assumption, which is not a conclusion based on evidence, must be verified in political, aesthetic, and educational practices. The quest is to investigate what the effect would be if we assume equal intelligence. This assumption goes against a common prejudice that some people/groups/'races' are less intelligent than others. It also forms the basis of coloniality. The assumption of equality is for Rancière an important element in the promotion of equality in society. 'Equal intelligence' recognizes the ability of the 'others' to participate in the democratic constitution of society (economy, politics, culture).

The task of emancipatory education is to verify in practice the effects of the assumption of equal intelligence, to see '... what can be done under that supposition' (Rancière, 1991: 46). Equal intelligence means that everyone, regardless of gender, class, 'race', age, and education, has an equal ability to make sense of the world without having someone explain it to them. The ability of everyone to learn through processes of trial and error is already present when children learn language without a teacher. They learn by using their own intelligence, and through processes such as trial and error, and also by comparing one utterance with another. 
The assumption that intelligence is equal does, however, not mean that it is exercised equally. This is because not everyone has the opportunity, the encouragement, the courage, the will, or the space to fully exercise his/her intelligence. The exercise of intelligence is an act of courage and will. It entails the expression of an own view and mode of becoming in opposition to a hegemonic order. It requires courage for a mind to break from the shackles of coloniality, or for the economically marginalized to relate the causes of poverty to the dominant division of the sensible. Courage and will are required when the marginalized are not only silenced and threatened, but particularly when they are merely ignored as insignificant. It is the courage to 'write what I like' (Biko, 1987).

\section{The sensible}

The presumption of equal intelligence means that everyone has the ability to 'partition' the 'sensible' differently. Sensemaking refers to the way sensual experiences are interpreted. The dominant view (partitioning) of the sensible world informs us that existing inequalities are caused by inherent differences and social inabilities. The assumption of equal intelligence asserts the ability of the 'others' to challenge the way sensible experience is divided.

While the sensible refers to the world as perceived and lived, the partition of the sensible refers to the dominant (hegemonic) experiences of the world. According to Rancière:

We will call 'partition of the sensible' a general law that defines the forms of part-taking by first defining the modes of perception in which they are inscribed. The partition of the sensible is the cutting-up of the world and of 'world;' it is the nemein upon which the nomoi of the community are founded. This partition should be understood in the double sense of the word: on the one hand, that which separates and excludes; on the other, that which allows participation. A partition of the sensible refers to the manner in which a relation between a shared 'common' [un commun partagé] and the distribution of exclusive parts is determined through the sensible. This latter form of distribution, in turn, itself presupposes a partition between what is visible and what is not, of what can be heard from the inaudible. (Rancière, 2001)

The sensible draws the parameters of daily life within a hegemonic world. It refers to the conditions of what is visible/invisible, sayable/unsayable, audible/inaudible. The distribution of the sensible is both an aesthetic and a political configuration where networks of power allow a particular distribution of sense.

\section{Aesthetics and Politics}

Aesthetics is for Rancière emancipatory since it is the terrain where the sensible could be partitioned differently. 
His analyses of the distribution of the sensible and the different regimes of art should be understood to highlight the emancipatory potential of aesthetics and the aesthetic regime of art rather than art in general, because it is aesthetics, and not art, that is constituted by dissensus and the practice of equality. (McQuillan, 2011: 21)

Aesthetics is political since it creates a dis-sensus about the hegemonic distribution of the sensible. To understand the political, it has to be distinguished from the police order. Police refers to the existing political order of parliaments and elections; to the social organization of groups, positions and functions; and to the economic relations of workers and owners. Policing entails the maintenance of the separation between those who take part, are visible and audible from those that are not. According to Rancière:

The essence of the police is to be a partition of the sensible characterized by the absence of a void or a supplement: society consists of groups dedicated to specific modes of action, in places where these occupations are exercised, in modes of being corresponding to these occupations and these places. In this fittingness of functions, places, and ways of being, there is no place for a void. It is this exclusion of what 'there is not' that is the policeprinciple at the heart of statist practices. ( 2001)

Politics, for Rancière, takes place when the police-order is disrupted:

The essence of politics, then, is to disturb this arrangement by supplementing it with a part of the no-part identified with the community as a whole. Political litigiousness/struggle is that which brings politics into being by separating it from the police that is, in turn, always attempting its disappearance either by crudely denying it, or by subsuming that logic to its own. Politics is first and foremost an intervention upon the visible and the sayable. (2001)

Politics is the interruption in the way the sensible is divided by presenting (making presence) the excluded, those who have no part. In this process the logic of sense is disrupted and changed. The political subjects are 'the part of those who have no-part', those without a name or voice, those who are invisible and inaudible. The police order could be disrupted by the subjectivity of equal intelligence. While the policing of consensus finds ways to include the subordinate within the current organization of the sensible, the politics of dissensus queries the ways the material reality is understood and experienced. Equal intelligence refers to the right and ability of the subordinate to fully participate in reconfiguring the world.

\section{Pedagogical relations}

Education is for Rancière central to awakening the equality of an intelligence that participates in the aesthetics of politics. The Ignorant Schoolmaster (Rancière) targets education as a terrain where inequalities are perpetuated through an 'explicative order' (1991: 4 ). The explicative order 
refers to a pedagogy where knowledge is transmitted from the informed educator to the ignorant student. In order for this pedagogical relation to exist a prior decision is taken about the inequality between educator and student. The distance that is created between the educator and the student could subsequently only be overcome through the transmission of the educator's knowledge. In this stultifying education, the educator is an expert on what the student does not know, about the inequality of the student and about the ways the gap should be overcome.

Rancière's problem with the explicative order is the presumption and verification of inequality through which the student is stultified. The pedagogy of explication is based on the assumed inequality and serves to perpetuate it. Where there is a need for explication, there is a prior decision that the sensible world cannot otherwise be grasped by the student. This can have no other outcome than the perpetuation of inequalities since student subjectivities remain characterized by ignorance.

The explicative order could only be challenged through the presumption of equal intelligence: the student is able to make his/her own sense of the world unmediated by the sense (intelligence) of the educator. It is therefore important for the emancipated educator to be aware of his/her own ignorance. While the educator might be knowledgeable about many things s/he is ignorant of the existence of inequalities as experienced by the student and of the sense the student will make of the world. The task of the emancipatory educator is to enable the student to exercise the own intelligence to the full.

This happens when the educator provides the student with a quest and ensures that s/he pursues it consistently. Rancière (1991) draws his inspiration from an 18th century teacher, Jacotot, who had the task to teach French to Flemish students. Since the 'ignorant schoolmaster' did not know any Flemish he simply gave them a French/Flemish parallel text with the task to start reading by comparing the two texts and to write a response in French. While he did not teach them any French, his task was to listen to students' responses, to interrogate and to verify.

In the relation between educator and the student, the intelligence of the educator does not play a part. Instead the will of the educator takes prominence. The pedagogical relation is between the will of the educator and the will of the student. The hope is for students to obtain the will and the desire to use their intelligence to partition the sensible differently. Emancipation 'takes place when an intelligence obeys only itself 'even while the will obeys another will' (Rancière, 1991: 13). In this process the educator does not judge how intelligence is used, only that it is used.

Emancipation for Rancière is not about learning in general, but about the reorganization of sense, the different interpretation of the sensible, of the way the world is organized. It is not the learning about established knowledges and established ways of organizing the world, but about the ability to organize it differently. A close relation is therefore needed between education, aesthetics, and politics. 


\section{Emancipatory spatial interferences}

We are now in a position to read diffractively the typology of space with the emancipatory pedagogy of Rancière. While progressive pedagogies emphasise fluid spaces, the spatial analysis of Rancière's pedagogy takes us in a different direction. This investigation reveals that regional space is not necessarily oppressive and that fluid spaces could not be equated with emancipatory pedagogies. Through the diffractive reading of the spatial topology with the critical pedagogy of Rancière the effects of the interferential agencies of regional - and fire spaces on the exercise of equal intelligence could be investigated.

\section{The regionality of the educator's will}

We find in Rancière's critical pedagogy a particular kind of return to bounded spaces. In Rancière's pedagogy selected aspects of regional space are performed in such a way that the knowledge of the teacher, a standard/form of knowledge, or a single identity is not imposed. On the other hand, boundaries are maintained, and a form of authority imposed.

Aspects of regional space are performed when the educator 'guards the door' so that students cannot escape from the demands of the quest. Rancière (1991) recounts how Jacotot's students were coerced to engage with the task while obstructing their escape. Rancière describes this relation as a 'circle of power': 'The master is the one who encloses an intelligence in the arbitrary circle from which it can only break out by becoming necessary to itself' (Rancière, 1991: 15). They have to engage in the task:

The book prevents escape. The route the student will take is unknown. But we know what he cannot escape: the exercise of his liberty. We know too that the master won't have the right to stand anywhere else-only at the door. The student must see everything for himself, compare and compare, and always respond to a three-part question: what do you see? what do you think about it? what do you make of it? And so on, to infinity. (Rancière, 1991: 23)

Regional space acts in such a way that the will and intellect of students are in a confined space. Regional space acts in such a way that the will of the educator is imposed on the will of the student. The educator wills the student to will in such a way that escape only happens when the quest is abandoned. The intellect of students is also confined in the sense that they are obliged to engage with the task where they have little choice other than engaging with the quest. The regional space makes it possible for the educator to exercise his/her will and prevent students from willing something different while remaining true to the quest. The educator

forbids the one to be emancipated the satisfaction of claiming that one is incapable of learning, thinking and acting for oneself. Oppression thus appears as the belief that one is unable to learn, think and act for oneself - a rejection of one's freedom - and emancipation concerns revealing 'an intelligence to itself. (Rancière, 1991: 28) 
The purpose of the performance of regionality is to focus the attention of the student on the intellectual demands of the task. The bounded space makes it possible for the will of the student to be controlled by the will of the educator and by the task from which students cannot escape. While regional space is something to escape from, it is, paradoxically, the place where freedom is found.

It should be clear that the notions of the 'ignorant schoolmaster' and 'equal intelligence' do not marginalize the educator or reduce the role of the educator to that of a facilitator. On the contrary, Rancière allocates a very strong role to the educator. The main task of the educator is to enable students to exercise their intelligence by igniting their will and courage. There are two 'fundamental acts' for the schoolmaster:

He interrogates, he demands speech, that is to say, the manifestation of an intelligence that wasn't aware of itself or that had given up ... he verifies that the work of the intelligence is done with attention. (Rancière, 1991: 29)

The educator does not ask about the outcome of the process, only whether the 'work' of intelligence has been done with attention. The verification of intelligence lies in 'what an intelligence can do when it considers itself equal to any other and considers any other equal to itself' (Rancière, 1991: 39).

While regionality is necessary for the awakening of the will of students, it is inappropriate when used to capture the intelligence of students when knowledge is transmitted, or explanations provided. In the Rancièrian pedagogy regional space enacts a wilful subjectivity committed to the pursuit of an own understanding. It is different from the subjectivity produced in the regional space of the explicative order (banking education) where inequalities are reproduced, knowledge transmitted, and stultification enhanced. Students, of course, always have a choice not to engage in the task and to find some kind of escape by refusing the coercive will of the educator.

\section{Firing student activism}

The Rancièrian pedagogy also enacts fire spaces once the will to intelligence is invoked. We notice here the fire elements of passion, energy, spirit, will, anger, creative destruction and sexuality (Law and Mol, 2001: 615) where the other participates and the outcomes cannot be predicted or controlled. Creativity is present when the emancipated student is the emancipated spectator in the theatre who is able to make their own sense. In the theatre

(T)the effect of the idiom cannot be anticipated. It requires spectators who play the role of active interpreters, who develop their own translation in order to appropriate the "story" and make it their own story. An emancipated community is a community of narrators and translators. (Rancière, 2009: 22) 
The flickering of presence and absence occurs when 'those with no part' start to become visible and to take part in redefining the sensible. The educator is present in his/her absence: While the intelligence of the educator is absent, his/her will is present to interrogate and verify.

The uncontrollability of fire happens when the others (those with no part) cannot be brought into the realm of the Same (the dominant order). While the Other becomes part of the Same in the explicatory pedagogy, the sameness of the police-order disintegrates through the multiple voices of the others. The interpretations of the emancipated spectator/student cannot be anticipated or predicted.

Anger, creative destruction, and energy are present in this aesthetic space where the consensual police-order is subverted through the different partitioning of the sensible. It is the making visible what has been rendered invisible by the police order which expels the void. This has revolutionary effects. Using their own aesthetic intelligence, students are able to imagine a partitioning of the sensible that differs from how it is done in dominant epistemologies and pedagogies of transmission. They are able to engage in an aesthetic politics of dissensus. The revolutionary multiplication of the sensible does not confront the police order head on but makes it impossible for any centre to hold.

The effect of fire has been described in emancipatory pedagogies such as Santos's (2018) notion of the pluriversity where many voices are heard. It could also be said with Fanon that decolonising pedagogies are programmes 'of complete disorder' (2004: 27). In the educational context fire spatialities could be associated with the assemblages of desire described by Olssen (2009) when pre-schoolers use an overhead projector to experiment with their bodies and light. Olssen (2009: $133 \mathrm{ff}$.) reports on how the teachers observed the intensity of children's desire and excitement when they are confronted with something new or with something they do not quite understand. The images presented on the screen prompted them to experiment further with different objects and effects of light and shadow. The teachers discovered that a continuing quest was present through the interaction between the children and between the children and the instruments, a quest that could not be easily domesticated or tamed.

In the context of higher education fire spaces are performed by students during the Baltimore protest in April/May 2015 as reported by Ford (2016). Using Lefebvre's notion of space, Ford (2016) distinguishes learning from studying when analysing how students protest police brutality and capitalist appropriation. While learning is tied to the existing order, studying takes place when an established order is disrupted through the generation of new spaces and knowledges. Students were studying when disrupting the normal capitalist ordering, occupying privatised spaces, and subverting the rule of exchange-value. In this process fire-spaces were performed when the disruption enables different understanding of the social, political, and economic order.

\section{Spatial interferences}

Law and Mol (2001) are interested in the effects when different types of space interfere. Interference (or diffraction in Haraway's (2018) terms) refers to the patterns of light and shadow 
when waves intersect. They argue that the interference of regional and network spaces enabled the 16th century Portuguese vessel to reach Calcutta across treacherous seas. This daunting expedition was possible because the vessel participated in two kinds of spaces as an immutable mobile. The immutability refers to its stability and endurance in network space while its mobility refers to its movement in regional space.

But it is that immutability in network space which affords both the immutability and the mobility in Euclidean space. To put it more strongly, it is the interference between the spatial systems that affords the vessel its special properties. We are in the presence of two topological systems, two ways of performing space. And the two are being linked together. (Law and Mol, 2001: 612)

Similarly, in the emancipatory pedagogy of Rancière the interference of regional - and fire spaces has the powerful effect of emancipation - the moment when students display the will and the courage to make their own sense of the world. A fire is ignited through the interference of the power of the will and the power of equal intelligence.

The interference points also to the simultaneity of spaces. The performance of regional space does not precede those of fire spaces. The interference of the two spaces implies that the strength of the coercion of the educator's will is proportional to the strength of the student's will. Performing emancipatory fire spaces does not leave the regional behind since the continual questioning of the emancipatory educator is always present: have you used your own intelligence or are you simply following a crowd or an established belief? The student would be on a trajectory of emancipation once the educator's questions are internalized. While the will of the student is awakened in regional space, it is exercised in fire space.

While education takes place in different places in the examples discussed by Mulcahy (2015), Edwards, et al. (2011), and Bayne, et al. (2014) the effects of interferences have not been articulated. When Mulcahy, for example, shows how children create their own safe spaces within a fluid classroom, it is portrayed more as a refuge than as a moment of empowerment. Bayne, et al. (2014) discuss the regional and network spaces of a residential university involved in distance teaching. The campus remains, however, the symbolic and affective centre for these distance students which prevents them from opportunities to reterritorialize given knowledges. It is also not clear from Ford's (2016) discussion exactly how the involvement of the teacher in the learning process impacts on students' studying.

\section{Conclusion}

Emancipatory pedagogies such as Freire's critical pedagogy (Freire, 2005) tend to favour fluid pedagogical spaces which break with the authoritarian educator and dominant forms of knowledge. It is believed that the egalitarian pedagogical relation would empower the student to become a subject in the knowledge generation processes. While fluidity is present in many instances of the critical pedagogy literature such as bell hooks's Teaching to Transgress (1994) 
or Giroux's Border Crossing (2005) ,the remnants of authority are not always accounted for. Rancière's emancipatory pedagogy deviates from other critical pedagogies: It deviates from the Marxist tradition where the knowledge of the educator is essential to the emancipation of the student. It also deviates from the Freirean tradition by allocating a very strong role to the educator. Rancière's decentering of the educator allows for the heterogeneous agency of space in education. The educator becomes part of the heterogeneous agency of spatial assemblages where the possibility of 'learning by chance' could be improved. In this process the focus shifts from the human agents (educator and student) towards the enactments with and through educational spaces. It is not the task of the educator to transmit anything to the student, however meaningful it may be deemed. While the text Rancière's Jacotot provided to students was not educationally significant as such, it did provide the opportunity for students to exercise their intelligence. Although nothing was transmitted, students were intellectually empowered and emancipated. This interpretation of the role of the educator differs from Biesta's (2017) insistence that something meaningful must be conveyed. When the agency of the educator is decentered within spatial performances, the possibility exists that meanings would be generated that exceed anything the educator could contribute. They generate something of meaning that could not be anticipated or controlled by the educator.

This article attempted to illustrate how the interference of different kinds of spaces could be conducive to emancipatory and decolonial pedagogies. Drawing on spatial enactments and using a typology of four types of spaces, the central argument is that none of these pedagogical spaces are emancipatory as such. It all depends on how differences, similarities, continuities, and breaks are enacted and what kind of subjectivity is produced when different kinds of spaces interfere. Mulcahy reports a view of a participant in her study: 'it's more about what's happening within the spaces than actually the spaces themselves' (2015: 509). She reports on how different spaces are enacted in schools in relation to the purposes.

When deploying an analytic of assemblage in policy research, the focus is not whether a particular concept of space (open, flexible, contained, traditional) is 'true' but whether it works, and whether it opens up possibilities in a given situation and for what and for whom it does this. (Mulcahy, 2015: 511)

We are in an epistemic crisis where the boundary between scientific/academic knowledge and common sense/fake truths is blurred. It may appear that Rancière contributes towards this blurring by assuming equal intelligence of the educator and student. He emphasizes, however, that equal intelligence is not a given or an entitlement and certainly not a popular form of knowledge. The verification of the equality of intelligence takes place when the world is enacted differently through revolutionary action. It has been shown how such an intelligence could be triggered and empowered through the effects of spatial diffractions. Bounded by the questioning of the emancipated educator the hope is that youthful revolutionary activism would ignite a fire that does not simply destroy, but which create spaces for new subjectivities and social orderings. 
Higher education pedagogies have to enable multiple divisions of the sensible, not by providing students with answers about the way the world is or should be, but by demanding students the will and courage to know (to decolonise Kant's sapere aude!) differently from an imposed form of knowledge. This is key to the enactment of the university within the contexts of coloniality and neoliberalism. The pedagogy of spatial interferences has the potential to not only disallow epistemic obedience (Mignolo, 2009) but also the verification of the intellectual equality of the South.

\section{Author biography}

Dirk Postma is an associate professor in the College of Education, Unisa. His research focusses on critical posthumanist approaches to education. He teaches in the fields of philosophy and research theories and methods in education and supervises local and international students. Dirk has been the chief editor of Education as Change from 2013 to 2020.

\section{References}

Barad, K. 2003. Posthumanist performativity: Toward an understanding of how matter comes to matter. Signs, 28(3): 801-831.

Bauman, Z. 2007. Liquid Times. Cambridge: Polity Press.

Bayne, S., Gallagher, M. S. \& Lamb, J.(2014. Being 'at' university: the social topologies of distance students. Higher Education: The International Journal of Higher Education and Educational Planning, 67: 569-583.

Biesta, G. J. J. 2017. Don't be fooled by ignorant schoolmasters: On the role of the teacher in emancipatory education. Policy Futures in Education, 15(1): 52-73.

Biko, S. B. 1987. I write what I like. Steve Biko: A selection of his writings. A. Stubbs (ed.) Oxford: Heinemann.

Boano, C. \& Kelling, E. 2013. Towards an architecture of dissensus: participatory urbanism in South-East Asia. Footprint. Delft Architecture Theory Journal, 13: 41-62.

Büscher-Ulbrich, D. 2020. Politics and the Production of Space: Downtown and out with Rancière and Lefebvre. In Kindermann, M. \& Rohleder, R. (eds.) Exploring the Spatiality of the City across Cultural Texts: Narrating Spaces, Reading Urbanity. Basingstoke: Palgrave.

Castells, M. 1996. The Rise of the Network Society. Oxford: Blackwell.

de Laet, M. \& Mol, A. 2000. The Zimbabwe Bush Pump: Mechanics of a Fluid Technology. Social Studies of Science, 30(2): 225-263.

Deranty, J.-P. 2007. Democratic aesthetics: On Jacques Rancière's latest work. Critical Horizons: A Journal of Philosophy and Social Theory, 8(2): 230-255.

Edwards, R. 2014. Spatial theory in networked learning. In Bayne, S., Jones, C., de Laat, M., Ryberg, T. \& Sinclair, C. (eds.) Proceedings of the 9th International Conference on Networked Learning. Edinburgh: University of Edinburgh, 526-532. 
Edwards, R., Tracy, F. \& Jordan, K. 2011. Mobilities, moorings and boundary marking in developing semantic technologies in educational practices. Research in Learning Technology, 19(3): 219-232.

Fanon, F. 2004. The Wretched of the Earth, trans. R. Philcox. New York: Grove Press.

Ferrare, J. J. \& Apple, M. W. 2010. Spatializing critical education: progress and cautions. Critical Studies in Education, 51(2): 209-221.

Ford, D. R. 2016. A pedagogy for space: Teaching, learning, and studying in the Baltimore Rebellion. Policy Futures in Education, 14(2): 176-193.

Freire, P. 2005. Pedagogy of the oppressed, trans. M. Ramos. New York: Continuum.

Giroux, H. A. 2005. Border Crossings. Cultural Workers and the Politics of Education. London: Routledge.

Grellier, J. 2013. Rhizomatic mapping: spaces for learning in higher education. Higher Education Research \& Development, 32(1): 83-95.

Gulson, K. N. \& Symes, C. (eds.) 2007. Spatial Theories of Education. New York: Routledge.

Haraway, D. J. 2018. Modest_Witness@Second_Millennium. FemaleMan@_Meets_ OncoMouseTM. New York: Routledge.

Hayles, N. K. 1999. How we became Posthuman. Virtual Bodies in Cybernetics, Literature and Informatics. Chicago: University of Chicago Press.

hooks, b. 1994. Teaching to Transgress. Education as the Practice of Freedom. London: Routledge.

Latour, B. 1987. Science in Action: How to Follow Scientists and Engineers through Society. Cambridge, Mass: Harvard University Press.

Latour, B. 1994. Where Are the Missing Masses? The Sociology of a Few Mundane Artifacts. In Bijker, W. E. \& Law, J. (eds.) Shaping Technology / Building Society: Studies in Sociotechnical Change. Cambridge: MIT Press, 225-258.

Law, J. \& Mol, A. 2001. Situating technoscience: An inquiry into spatialities. Environment and Planning. Society and Space, 19: 609-621.

Law, J. \& Singleton, V. 2005. Object lessons. Organization, 12(3): 331-355.

Lefebvre, H. 1991. The Production of Space, trans. D. Nicholson-Smith.Oxford: Blackwell.

McLaren, P. 199. Revolutionary Multiculturalism: Pedagogies of Dissent for the New Millennium. Boulder, CO: Westview Press.

McQuillan. 2011. The intelligence of sense: Rancière's aesthetics. Symposium: Canadian Journal of Continental Philosophy, 15(2): 11-27.

Mignolo, W. D. 2009. Epistemic disobedience, independent thought and de-colonial freedom. Theory Culture \& Society, 26(7-8): 1-23.

Mol, A. \& Law, J. 1994. Regions, networks and fluids: Anaemia and social topology. Social Studies of Science, 24: 641-671.

Mulcahy, D. 2007. Managing spaces: (re)working relations of strategy and spatiality in vocational education and training. Studies in Continuing Education, 29(2): 143-162. 
Mulcahy, D. 2015. Re/assembling spaces of learning in Victorian government schools: policy enactments, pedagogic encounters and micropolitics. Discourse: Studies in the Cultural Politics of Education, 36(4): 500-514.

Olsson, L. M. 2009. Movement and Experimentation in Young Children's Learning. Deleuze and Guattari in Early Childhood Education. London: Routledge.

Rancière, J. 1991. The Ignorant Schoolmaster. Five Lessons in Intellectual Emancipation, trans. K Ross. Stanford: Stanford University Press.

Rancière, J. 2001. Ten theses on politics. Theory \& Event, 5(3).

Rancière, J. 2009. The Emancipated Spectator, trans. G. Elliott. London: Verso.

Rancière, J. 2012. Proletarian Nights. The Workers' Dream in Nineteenth-Century France, trans. J. Drury. London: Verso.

Santos, B. de S. 2018. The End of the Cognitive Empire. The Coming of Age of Epistemologies of the South. Durham: Duke University Press.

Smith, L. T. 2012. Decolonizing Methodologies. Research and Indigenous People. 2nd edition. London: Zed Books.

Sørensen, E. 2009. The Materiality of Learning. Cambridge, MA: Cambridge University Press.

Walker, M. \& Wilson-Strydom, M. (eds.) 2017. Socially Just Pedagogies, Capabilities and Quality in Higher Education. London: Palgrave MacMillan.

Wubbena, Z. 2017. A pedagogy for space: Visually framing the 2011 Chilean student movement. Policy Futures in Education, 15(4): 460-480. 